\title{
Introduction and Comments
}

\author{
James Johnson
}

T his is the first issue of Perspectives to contain material nearly all of which began the review process under my editorship. It also is the first issue under my editorship to contain contributions to the somewhat illdefined section called "Perspectives." To the best of my knowledge this also is the first time a symposium has run in this section. As our Submission Guidelines state, essays that fit this genre are not meant to be full-fledged academic research papers but rather "short, sharp commentaries on a political phenomenon or policy problem; dialogues or debates to highlight methodological or substantive disagreements; or insights into or evaluation of other works of interest to political scientists."

The issue opens, by design, with just such a set of interventions in the form of a symposium entitled " 25 Years at the Margins: The Global Politics of HIV/AIDS." I say by design because the symposium is intended to commemorate the initial scientific documentation in 1981 of the HIV virus. However, our aim in publishing, and indeed in leading off with, the symposium is not simply to commemorate. Whether explicitly or implicitly all of the contributions to the symposium also remonstrate with the discipline and its intellectual priorities. As Andrea Densham points out in her introduction, with a handful of prominent exceptions, political scientists largely have neglected the comparative, domestic, and international politics of HIV/ AIDS. The remaining four contributions make no claim to be comprehensive but aim instead to indicate the scope and scale of the ongoing AIDS epidemic and some of its political causes and consequences across a diverse array of cases-France, South Africa, Brazil, Barbados, Malaysia, and Singapore. By implication the contributors highlight too the scope and scale of our neglect.

Upon reading the penultimate version of the symposium I considered the possibility that this charge might perhaps be overstated. As far as I have been able to ascertain, it is not. A quick search on JSTOR and the Social Science Citation Index suggests that with only extremely rare exceptions, over the past quarter century none of the top dozen or so general or specialized journals in the discipline or its primary sub-fields have published so much as a single research article directly addressing the politics of HIV/AIDS. I am sure that that claim will be challenged but I also am confident that any correction I might be compelled to make will be marginal. The exceptions, if any might be found, will prove the rule. It is crucial to add that we political scientists cannot simply plead ignorance or irrelevance here since as long ago as 1992 Kenneth Sherrill, Carolyn Somerville, and Robert Bailey had indicated quite forcefully "What Political Science Is Missing by Not Studying AIDS" (PS: Political Science \& Politics 25(4):688-93). Having said all that, I ask you not to read this symposium simply as an indictment. That would be a mistake. The contributors to the symposium are extending an invitation, one imploring that we focus our intellectual energies and research skills on what indisputably remains a very urgent set of political problems. I urge political scientists to accept the invitation. Indeed, the pages of Perspectives on Politics would provide a perfect forum for the results that such inquiry might generate.

I wish to thank Meredith Weiss and Michael Bosia for approaching me with the idea of publishing this symposium in the first place and for their subsequent hard work at coordinating the contributions. I also would like to thank all the contributors for writing and re-writing under tight deadlines so that the symposium could indeed appear in this 25 th year of the epidemic. Finally, I would like to thank two referees-Mark Blasius and Richard Parkerwho, also under tight deadlines and despite other personal pressures, read the entire symposium and offered insightful advice about ways to improve it.

The reminder of this issue contains three excellent, more familiar, if still provocative examples of what political scientists do very well. Each of the articles focuses on the sources of shared political identities and how we might analyze and assess them. Timothy Byrnes and Peter Katzenstein explore the confluence of "transnational religions"Catholicism, Islam, and Orthodox Christianity-and politics in contemporary Europe. They argue that scholars of International Relations must pay more consistent attention to this intersection. Yet if religion affords political actors one crucially important source of identity, it remains to be seen just how we ought to approach it. Rawi Abdelal, Yoshiko Herrerra, Alasdair Johnston, and Rose 
McDermott address that problem. They advance a framework for studying collective identity that provides, in their words, greater "rigor and precision" than extant approaches. They see such identities as varying across two dimensionsthe meaning a given identity holds for relevant constituencies and the level of agreement that obtains regarding such meaning within a given population. Finally, Russell Muirhead offers a cogent, if qualified, defense of one source of collective identity that simultaneously is very salient and much maligned, namely partisanship.

I will conclude on a note of sadness. Iris Marion Young died this past summer of cancer. She was a smart, influential political theorist as well as a committed feminist and democrat. I admired her intelligence and her politics even where we disagreed. I did not know Iris well but last year invited her to serve as an Associate Editor of this journal. By then, Iris already had fought through the initial treatments for her cancer. We nonetheless had a couple of long, frank phone conversations during which I tried to persuade her to sign on and she pressed me very hard on the direction I wanted to take the journal. It is safe to say that she remained somewhat skeptical yet, in the end, Iris graciously agreed to join the Associate Editors. I joked after our conversations that she did so mostly to keep an eye on me! I always have thought that the title of Iris's (recently republished) essay "Throwing Like a Girl" nicely captured the combination of incisiveness and humor that were among her most obvious characteristics. It is, I think, appropriate that the symposium on "The Global Politics of HIV/AIDS" published here addresses themes of justice, gender, and sexuality within a transnational frame that Iris would appreciate.

\section{Notes from the Managing Editor}

\section{Forthcoming}

The following articles and essays have been scheduled for publication in a forthcoming issue of Perspectives on Politics.

Jack Citrin, Amy Lerman, Michael Murakami, and Kathryn Pearson. "Testing Huntington: Is Hispanic Immigration a Threat to American Identity?"

Martin Elff. "Social Structure and Electoral Behavior in Comparative Perspective: The Decline of Social Cleavages in Western Europe Revisited"

Ange-Marie Hancock. "When Multiplication Doesn't Equal Quick Addition: Examining Intersectionality as a Research Paradigm"

Lisa L. Miller. "The Representational Biases of Federalism: Scope and Bias in the Political Process, Revisited"

Gregory W. White. "The International Political Economy of Development: Development and Its Persistent Scare Quotes" 